\title{
Reproductive Toxicity of Eugenol in Wistar Rats
}

\author{
Toxicidade Reprodutiva do Eugenol em Ratas Wistar
}

Toxicidad para la Reproducción del Eugenol en Ratas Wistar

Jamilka Leopoldina da Silva ${ }^{1 *}$, Anne Catharine Tavares de Azevedo Marinho ${ }^{1}$, Lady Dayane Kalline Travassos dos Prazeres ${ }^{1}$, Teresinha Gonçalves da Silva ${ }^{1}$, Kleison da Costa Merlo', Henrique Bandeira Alves Costa ${ }^{1}$, Almir Gonçalves Wanderley ${ }^{1}$.

\begin{abstract}
Objective: To analyze the effects of eugenol oral administration during pre-implantation and organogenesis periods in pregnant Wistar rats. Methodology: The animals were divided into eight experimental groups (4 groups for each period) subdivided into control groups and daily treated with eugenol at doses of $37.5,187.5$ and $375 \mathrm{mg} / \mathrm{kg} /$ day $(\mathrm{n}=9)$ during pre-implantation or organogenesis phases. Results: At all tested doses of eugenol, the groups treated during the pre-implantation presented alterations in the maternal organs, increased pre-and post-implantation loss and stillbirth records. The groups treated during organogenesis also presented alterations in the maternal organs and reduction of the placental indexes, added to the skeletal alterations, in all treatment doses. There were no significant fetal visceral changes. Conclusions: Oral administration of eugenol reduced maternal reproductive capacity in the pre-implantation phase and promoted toxic effects and fetal malformations in organogenesis.
\end{abstract}

Keywords: Eugenol, Organogenesis, Reproduction, Toxicity.

\section{RESUMO}

Objetivo: Analisar os efeitos da administração oral do eugenol realizada durante os períodos de préimplantação e organogênese em ratas Wistar. Metodologia: Os animais foram divididos em oito grupos experimentais (sendo quatro grupos para cada período) subdivididos em grupos controle e tratados com eugenol nas doses de $37,5,187,5$ e $375 \mathrm{mg} / \mathrm{kg} / \mathrm{dia}(\mathrm{n}=9)$ diariamente durante as fases de pré-implantação ou organogênese. Resultados: Em todas as doses testadas de eugenol, os grupos tratados durante a préimplantação apresentaram alterações nos órgãos maternos, aumento da perda pré e pós-implantação e registros de natimortos. Os grupos tratados durante a organogênese também apresentaram alterações nos órgãos maternos e redução dos índices placentários, somados às alterações esqueléticas, em todas as doses de tratamento. Alterações viscerais fetais não foram significativas. Conclusões: A administração oral do eugenol reduziu a capacidade reprodutiva materna na pré-implantação e promoveu efeitos tóxicos e malformações fetais na organogênese.

Palavras-chave: Eugenol, Organogênese, Reprodução, Toxicidade.

1 Universidade Federal de Pernambuco (UFPE), Recife-Pernambuco. `E-mail: jamilka.silva@ufpe.br

Funded by the National Council for Scientific and Technological Development (CNPq): Postgraduate scholarship (Ph.D.), case number 140554/2015-7.

SUBMETIDO EM: 9/2019 | ACEITO EM: 10/2019 | PUBLICADO EM: 12/2019 


\section{RESUMEN}

Objetivo: Analizar los efectos de la administración oral de eugenol durante los períodos de preimplantación y organogénesis en ratas Wistar. Metodología: Los animales se dividieron en ocho grupos experimentales (4 grupos para cada período) subdivididos en grupos de control y tratados con eugenol a dosis de 37,5, 187,5 y $375 \mathrm{mg} / \mathrm{kg} / \mathrm{día}(\mathrm{n}=9$ ) diariamente durante fases de preimplantación u organogénesis. Resultados: en todas las dosis probadas de eugenol, los grupos tratados durante la preimplantación presentaron alteraciones en los órganos maternos, aumento de la perdida pre y postimplantación y registros de mortinatos. Los grupos tratados durante la organogénesis también presentaron alteraciones en los órganos maternos y reducción de los índices placentarios, sumado a las alteraciones esqueléticas, en las tres dosis de tratamiento. No hubo cambios viscerales fetales significativos. Conclusiones: La administración oral de eugenol redujo la capacidad reproductiva materna en la fase de preimplantación y promovió los efectos tóxicos y las malformaciones fetales en la organogénesis.

Palabras clave: Eugenol, Organogénesis, Reproducción, Toxicidad.

\section{INTRODUCTION}

Essential oils are characterized by their volatility and aroma, exploited in the food, pharmaceutical, and cosmetic industries, cleaning products, among others (NAEEM A, et al., 2018). Eugenol (4-allyl-2methoxyphenyl) is a naturally occurring aromatic compound in essential oils of several plants, especially clove (Syzygium aromaticum) (SANTIN JR, et al., 2011). This monoterpene is used as a synthetic food flavoring and has biological properties of medicinal interest, with extensive pharmaceutical and therapeutic use (CHATTERJEE D and BHATTACHARJEE P, 2015).

Among the properties of eugenol are recognized the actions such as antioxidant (GÜLÇIN I, 2011), antiemetic (CHARANTIMATHS and OSWAL R, 2011), antimicrobial (SILVA FFM, et al., 2018), anxiolytic (WANG X, et al., 2017), neuroprotective (SAID MM and RABO MM, 2017), antinociceptive (BÓ WD, et al., 2013), anticancer (SHARMA UK, et al., 2016), among others.

Exposure to eugenol commonly occurs in industrial and dental environments, through contact with tobacco, wood and marijuana smoke, in soaps, lotions, detergents, perfumes, and the consumption of many foods and beverages (NTP, 1999). Although eugenol is considered a safe compound (FDA, 2018), studies on its toxicological potential are limited, especially about interferences in the animal reproductive period.

In an in vivo model study, the inclusion of eugenol in mice diet two weeks before mating and from the day0 to day-4 of pregnancy, promoted difficulty in implantation of the blastocyst in the uterus, increasing the incidence of cell death (DOMARACKÝ M, et al., 2007).

Liu $\mathrm{H}$, et al. (2017) observed the embryotoxicity of eugenol in vitro (ID50: $5.43 \pm 0.72 \mu \mathrm{g} / \mathrm{ml}$ ) on embryonic stem cell culture. Despite the large pharmacological contribution of eugenol, there is not enough data in the literature to discuss the safety of using this compound during gestational phases in rats.

The maternal-fetal toxicological evaluation plays a fundamental role in the knowledge of the possible risks of eugenol in pregnancy. Thus, the present study aimed to analyze the effects of eugenol oral administration during pre-implantation and organogenesis periods in Wistar rats.

\section{METHODS}

\section{Animals}

The animals were maintained under controlled conditions of temperature $\left(22 \pm 3^{\circ} \mathrm{C}\right)$, humidity $(50-60 \%)$, and lighting (12/12h light-dark cycle). They were fed with commercial dry food (Presence®, Purina, Brazil) 
and water "ad libitum". Were utilized adult Wistar rats (Rattus norvegicus albinus) of both sexes, weighing between 250 and 300g; approximately 12 weeks old obtained from the Department of Physiology and Pharmacology of the Federal University of Pernambuco (UFPE). All experimental protocols were submitted to the Animal Experimentation Ethics Committee (CEUA) of the UFPE and approved under process $n^{\circ}$ $0041 / 2017$.

\section{Compounds and reagents}

Eugenol (CAS \# 97-53-0, 99\% purity, Sigma Aldrich®, St. Louis, EUA) was dissolved in aqueous solution containing 2\% Tween 80 (CAS \# 9005-65-6, $\geq 99 \%$ purity, Sigma Aldrich ${ }^{\circledR}$, St. Louis, EUA) and both diluted in drinking water.

For general anesthesia of the animals was used $2 \%$ (air/O2) Isoflurano (CAS \# 26675-46-7, Roche, SP, Brazil) by inhalation. For visceral and skeletal analyses were used: acetone (CAS \# 67-64-1, $\geq 99.62 \%$ purity, Merck, SP, Brazil); glacial acetic acid P.A. (CAS \# 64-19-7, Química Moderna, SP, Brazil); 95\% ethyl alcohol P.A. (CAS \# 64-17-5, Química Moderna, SP, Brazil); alizarin red P.A. (CAS \# 72-48-0, Dinâmica Química Contemporânea, SP, Brazil); formaldehyde (CAS \# 50-00-0, 37\% P.A., Neon Comercial, SP, Brazil); pure bidistilled glycerin (CAS \# 56-81-5, Merck, SP, Brazil); and potassium hydroxide P.A. (CAS \# 1310-58-3, Dinâmica Química Contemporânea, SP, Brazil).

\section{Mating and experimental groups}

According to OECD Guideline 421 (OECD, 2016), nulliparous females were mated with adult males (1:1) at the beginning of the dark phase cycle. After 12 hours (at the beginning of the light phase) vaginal lavage was collected with $0.9 \%(\mathrm{w} / \mathrm{v}) \mathrm{NaCl}$ for further analysis under optical microscopy. The observation of spermatozoa on slides associated with the presence of estrous phase cells characterized the mating and determined pregnancy day-zero (D0) (COOPER RL, et al., 1993).

After pregnancy identification, the female rats were randomly divided into eight experimental groups $(\mathrm{n}=$ 9/group), with four groups treated during the pre-implantation phase ( 0 to the $5^{\text {th }}$ day of pregnancy) and four treated during the organogenesis phase ( $6^{\text {th }}$ to $15^{\text {th }}$ day of pregnancy).

The animals received, at specific periods, either vehicle as control $2 \%$ Tween 80 in water $(5 \mathrm{ml} / \mathrm{kg})$ or eugenol at doses of 37.5 (E1), 187.5 (E2) and $375 \mathrm{mg} / \mathrm{kg} /$ day (E3). The doses were chosen based on a previous study of our research group.

\section{Analysis of maternal toxicity}

Female rats were observed daily during pregnancy for possible behavioral changes, mortality, water, and food intake, piloerection, diarrhea, and vaginal bleeding (OECD, 2016).

\section{Evaluation of maternal reproductive performance}

On the $21^{\text {st }}$ day of pregnancy, the rats were anesthetized according to the National Council for Animal Experimentation Control (CONCEA) euthanasia practice guidelines (BRASIL, 2015), with2\% isoflurano (air/O $\mathrm{O}_{2}$ ) by inhalation, laparotomized and euthanized by cardiac incision. Then, ovariectomy was performed to count the number of corpora lutea. In the uterine horns, macroscopic evaluations were performed for the presence of live or dead fetuses, the number of implantation sites and early or late reabsorption.

Fetuses, placentas, reproductive and other maternal organs (thymus, heart, lungs, liver, kidneys, adrenals, stomach, pancreas and spleen) were weighed and analyzed for macroscopic malformations, determinations of fetal-maternal relationship, relative mass of maternal organs and reproductive implantation indexes, preand post-implantation losses and also the reabsorption indexes, according to Costa-Silva JH, et al. (2006).

\section{Evaluation of embryo-fetal toxicity in pre-implantation and organogenesis phases}

After the hysterectomy, the fetuses were weighed, sexed, after that the placental index and sex ratio were calculated. For calculation, the litters were considered as an experimental unit. 


\section{Visceral analysis in organogenesis}

Half of each litter was fixed in Bouin solution $(50 \mathrm{ml}$ formaldehyde, $50 \mathrm{ml}$ acetic acid, $752 \mathrm{ml} 95 \%$ ethyl alcohol and $148 \mathrm{ml}$ distilled water) for one week for subsequent visceral examination according to serial section method by Wilson J (1965).

\section{Skeletal analysis in organogenesis}

The other half of the litter was stained with alizarin red for skeletal analysis following an adapted protocol from Staples RE and Schnell VL (1964).

The fetuses were immersed in acetone for $24 \mathrm{~h}, 1 \%(\mathrm{w} / \mathrm{v})$ aqueous potassium hydroxide $(\mathrm{KOH})$ solution for $24 \mathrm{~h}$ and alizarin red solution $(0.50 \mathrm{mg})$ in $200 \mathrm{ml}$ of $1 \%(\mathrm{w} / \mathrm{v}) \mathrm{KOH}$ every $24 \mathrm{~h}$ for four days.

Were analyzed: the number, shape, and location of bones to confirm fetal alterations and malformations according to criteria proposed by Solecki $R$, et al. (2001). The counting and analysis of ossification points were performed according to Aliverti V, et al. (1979).

\section{Statistical analysis}

Samples were subjected to the Shapiro-Wilk normality test to determine normality. Results were expressed as mean \pm standard error of the mean (SEM) or median.

Differences between groups were determined by one-way ANOVA followed by Dunnett's post-test or Kruskal-Wallis test followed by Dunn's post-test when applicable.

For the analysis of skeletal and visceral malformations, Pearson's chi-square test was used. All statistical analyses were performed by GraphPad Prism 6.0 (GraphPad Software Inc., La Jolla, CA, USA) and p<0.05 was accepted as statistically significant.

\section{RESULTS}

Oral administration of eugenol at doses of 37.5 (E1); 187.5 (E2) and $375 \mathrm{mg} / \mathrm{kg}$ (E3) in the reproductive toxicity experiment did not cause death, behavioral changes or clinical signs of toxicity in the treated progenitors during the pre-implantation period ( 0 to $5^{\text {th }}$ day of pregnancy) nor during organogenesis $\left(6^{\text {th }}\right.$ to $15^{\text {th }}$ day of pregnancy).

On day- 1 of pre-implantation, water consumption was significantly increased by $48.8 \%$ in E3 group ( $57.0 \pm$ $4.4 \mathrm{ml} /$ day/animal) compared to control group (C) (38.3 $\pm 4.7 \mathrm{ml} /$ day/animal).

On day-2, food intake was significantly reduced by $19.7 \%$ and $24 \%$ in E2 (16.7 $\pm 1.3 \mathrm{~g} /$ day/animal) and E3 (15.8 $\pm 1.0 \mathrm{~g} /$ day/animal) groups, respectively, compared to the control group $(20.8 \pm 1.2 \mathrm{~g} /$ day/animal).

In the organogenesis no significant differences were observed in the water intake of the treated groups when compared to the control group.

However, food intake was significantly reduced by $26.4 \%$ on day-7 (14.89 $\pm 1.69 \mathrm{~g} /$ day/animal) versus (C: $20.22 \pm 0.92 \mathrm{~g} /$ day/animal); $25.7 \%$ on day-8 (14.44 $\pm 1.70 \mathrm{~g} /$ day/animal) versus (C: $19.44 \pm 1.78 \mathrm{~g} /$ day/animal); $29.5 \%$ on day 11 (15.11 $\pm 1.28 \mathrm{~g} /$ day/animal) versus (C: $21.44 \pm 1.69 \mathrm{~g} /$ day/animal) and $27.3 \%$ on day- 15 (16.22 $\pm 1.40 \mathrm{~g} /$ day/animal) versus (C: $22.33 \pm 1.72 \mathrm{~g} /$ day/animal) in E3 group.

Despite the reported dietary variations, there was no interference in body weight of the treated females, either in the pre-implantation or organogenesis phases (Figure 1). During pre-implantation, significant reduction of $21.4 \%$ in absolute ovarian mass were observed in the E3 group when compared to the control group. E2 group presented a reduction of $34.6 \%$ in the absolute mass of the placentas when compared to the control group. Relative placental masses also showed a significant reduction of $98.1 \%$ in the E3 group and $97.5 \%$ in E1 and E2 groups, compared with the control group. A significant reduction of $21.3 \%$ in the absolute pancreas mass was also observed in the E3 group when compared to the control group (Table 1). 
Figure 1 - Water and food intake and body weight evolution of eugenol-treated females during pre-implantation and organogenesis.
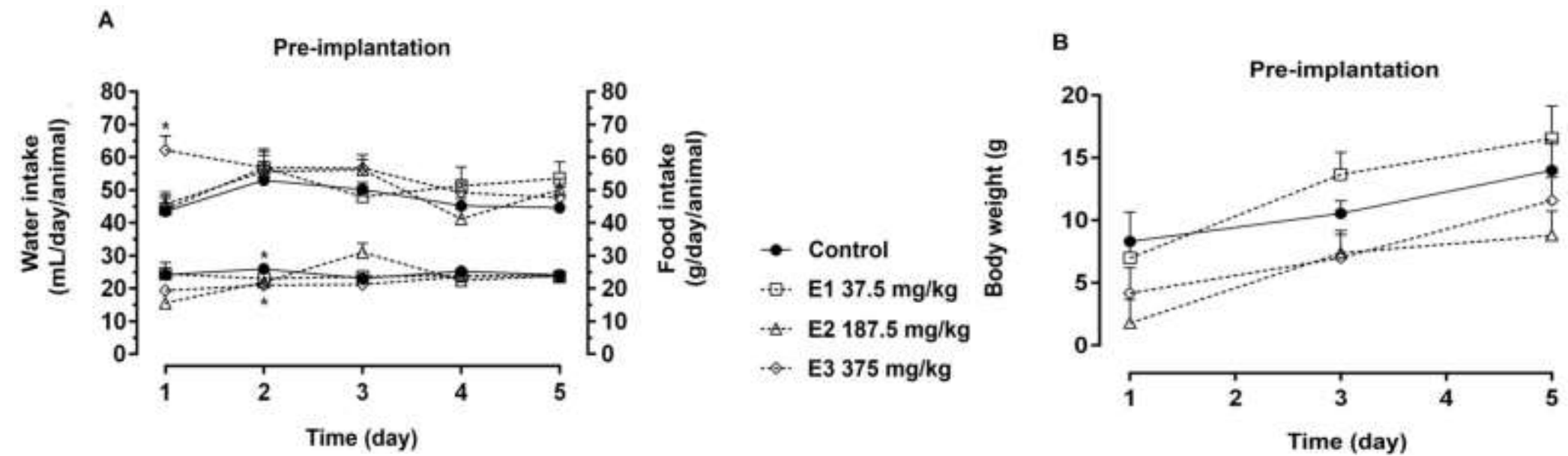

D
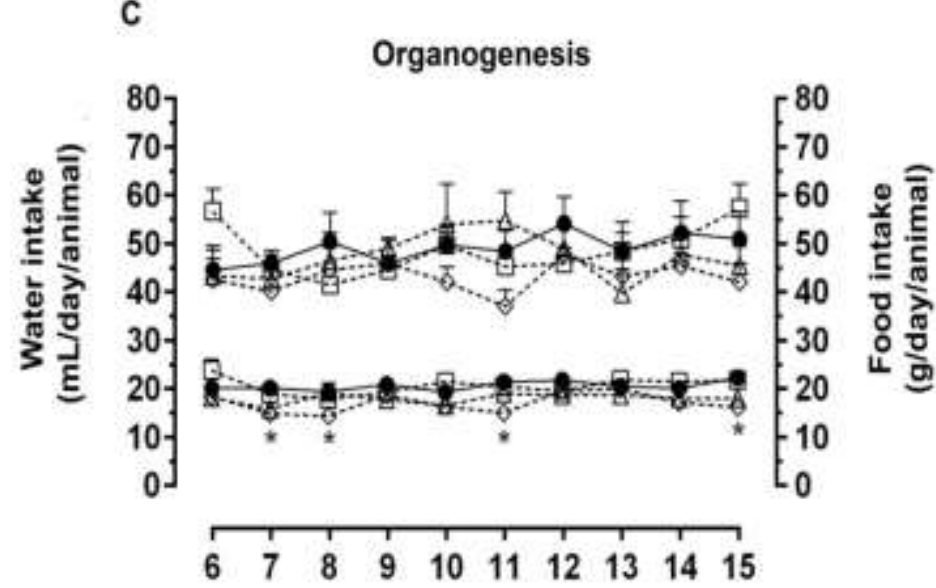

Time (day)
- Control

․․ E1 $37.5 \mathrm{mg} / \mathrm{kg}$

A. E2 $187.5 \mathrm{mg} / \mathrm{kg}$

$\leftrightarrow$ E3 $375 \mathrm{mg} / \mathrm{kg}$

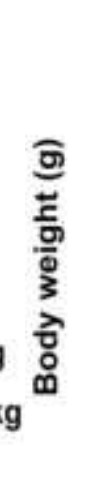

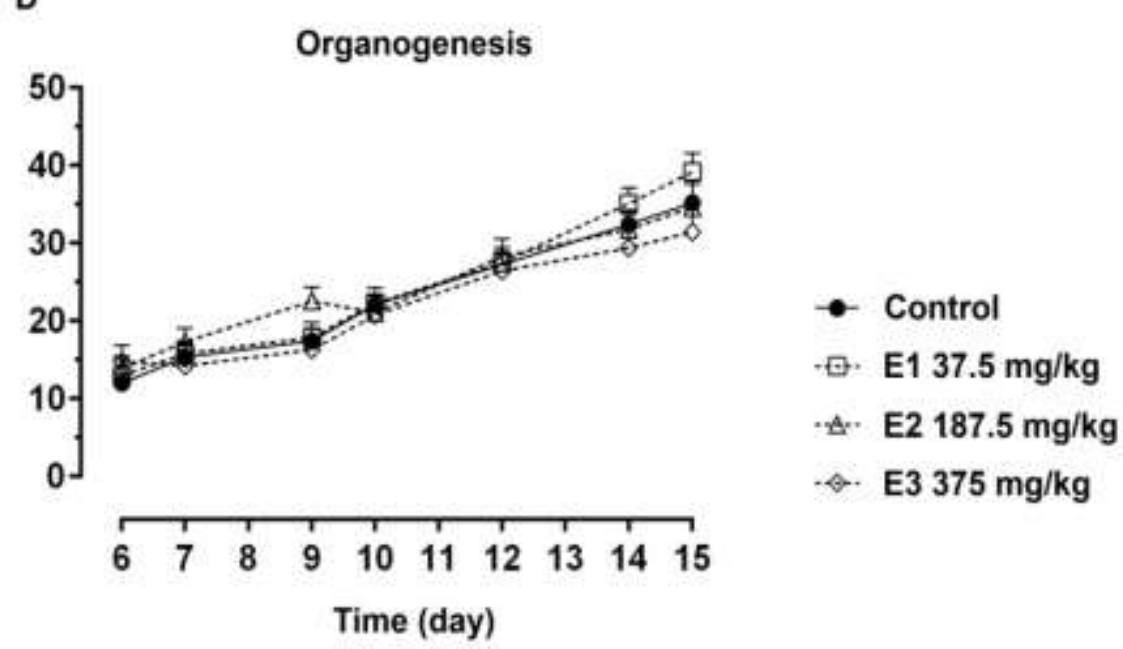

-- Control

나. E1 $37.5 \mathrm{mg} / \mathrm{kg}$

A. E2 $187.5 \mathrm{mg} / \mathrm{kg}$

- E3 $375 \mathrm{mg} / \mathrm{kg}$

Subtitle: Effects of eugenol oral admir weight in the respective gestational phases (B, $<0.05$. Source: Silva JL, et al., 2019. 
Table 1 - Effect of eugenol oral administration on absolute $(\mathrm{g})$ and relative $(\%)$ weight of maternal organs during the pre-implantation phase in Wistar rats.

\begin{tabular}{|c|c|c|c|c|c|c|c|c|}
\hline \multirow[b]{2}{*}{ Organs } & \multirow[b]{2}{*}{ Mass $(g)$} & ontrol & \multicolumn{2}{|c|}{$\begin{array}{c}\mathrm{E} 1 \\
(37.5 \\
\mathrm{mg} / \mathrm{kg})\end{array}$} & \multicolumn{2}{|c|}{$\begin{array}{c}\text { E2 } \\
(187.5 \\
\mathrm{mg} / \mathrm{kg})\end{array}$} & \multicolumn{2}{|c|}{$\begin{array}{c}\text { E3 } \\
(375 \\
\mathrm{mg} / \mathrm{kg})\end{array}$} \\
\hline & & Relative (\%) & Mass (g) & Relative (\%) & Mass (g) & Relative (\%) & Mass (g) & Relative (\%) \\
\hline Ovaries & $0.14 \pm 0.01$ & $0.04 \pm 0.00$ & $0.14 \pm 0.01$ & $0.04 \pm 0.00$ & $0.12 \pm 0.00$ & $0.04 \pm 0.00$ & $0.11 \pm 0.01^{* *}$ & $0.03 \pm 0.00$ \\
\hline Placentas & $5.72 \pm 0.44$ & $1.62 \pm 0.10$ & $5.09 \pm 0.53$ & $0.04 \pm 0.00^{* \star * *}$ & $3.74 \pm 0.40^{*}$ & $0.04 \pm 0.00^{* \star *}$ & $5.33 \pm 0.60$ & $0.03 \pm 0.00^{*+*+*}$ \\
\hline Pancreas & $0.94 \pm 0.06$ & $0.27 \pm 0.02$ & $0.78 \pm 0.04$ & $0.24 \pm 0.01$ & $0.94 \pm 0.06$ & $0.31 \pm 0.03$ & $0.74 \pm 0.05^{\star}$ & $0.22 \pm 0.01$ \\
\hline Thymus & $0.36 \pm 0.04$ & $0.10 \pm 0.01$ & $0.36 \pm 0.04$ & $0.11 \pm 0.01$ & $0.32 \pm 0.03$ & $0.10 \pm 0.01$ & $0.29 \pm 0.02$ & $0.09 \pm 0.01$ \\
\hline Heart & $0.96 \pm 0.03$ & $0.27 \pm 0.00$ & $0.91 \pm 0.03$ & $0.28 \pm 0.01$ & $0.94 \pm 0.04$ & $0.31 \pm 0.02$ & $0.94 \pm 0.02$ & $0.27 \pm 0.01$ \\
\hline Lungs & $1.73 \pm 0.14$ & $0.49 \pm 0.04$ & $1.59 \pm 0.08$ & $0.49 \pm 0.03$ & $1.68 \pm 0.10$ & $0.55 \pm 0.03$ & $1.82 \pm 0.10$ & $0.54 \pm 0.03$ \\
\hline Liver & $14.81 \pm 0.69$ & $4.21 \pm 0.09$ & $13.83 \pm 0.47$ & $4.26 \pm 0.14$ & $13.24 \pm 0.41$ & $4.33 \pm 0.22$ & $14.04 \pm 0.51$ & $4.10 \pm 0.11$ \\
\hline Kidneys & $2.26 \pm 0.07$ & $0.64 \pm 0.01$ & $2.10 \pm 0.05$ & $0.65 \pm 0.03$ & $2.04 \pm 0.09$ & $0.67 \pm 0.04$ & $2.18 \pm 0.06$ & $0.64 \pm 0.02$ \\
\hline Adrenals & $0.10 \pm 0.01$ & $0.03 \pm 0.00$ & $0.09 \pm 0.00$ & $0.03 \pm 0.00$ & $0.10 \pm 0.00$ & $0.03 \pm 0.00$ & $0.10 \pm 0.00$ & $0.03 \pm 0.00$ \\
\hline Spleen & $0.67 \pm 0.09$ & $0.19 \pm 0.02$ & $0.72 \pm 0.07$ & $0.22 \pm 0.02$ & $0.90 \pm 0.09$ & $0.29 \pm 0.02$ & $0.95 \pm 0.15$ & $0.28 \pm 0.05$ \\
\hline Stomach & $1.71 \pm 0.05$ & $0.50 \pm 0.02$ & $1.57 \pm 0.06$ & $0.48 \pm 0.01$ & $1.68 \pm 0.07$ & $0.52 \pm 0.02$ & $1.68 \pm 0.03$ & $0.49 \pm 0.02$ \\
\hline $\begin{array}{c}\text { Pregnancy } \\
\text { uterus }\end{array}$ & $58.46 \pm 4.23$ & $16.49 \pm 1.05$ & $50.01 \pm 3.49$ & $15.39 \pm 1.04$ & $45.05 \pm 3.30$ & $13.89 \pm 0.89$ & $46.66 \pm 8.43$ & $13.30 \pm 2.34$ \\
\hline
\end{tabular}

Subtitle: The values represent the mean \pm S.E.M. analyzed by one-way ANOVA, followed by Dunnett's test $(n=9 / g r o u p)$ and the statistical differences represent ${ }^{*} p$ $<0.05,{ }^{* *} \mathrm{p}<0.01,{ }^{* * \star *} \mathrm{p}<0.0001$, respectively. Relative organ masses were calculated by the ratio of organ weight and body weight on the last day of gestation $\mathrm{x}$ 100.

Source: Silva JL, et al., 2019. 
The visceral analysis showed the presence of evident changes in the female organs after the pre-implantation and organogenesis phases. At the doses of 187.5 (E2) and $375 \mathrm{mg} / \mathrm{kg}$ (E3), a higher number of affected organs and alterations were observed. The control and E1 groups showed similar results between themselves, without any alterations during the pre-implantation phase (Frame 1).

Frame 1 - Changes in maternal organs after daily treatment with eugenol in pre-implantation and organogenesis phases.

\begin{tabular}{|c|c|c|c|c|c|c|}
\hline \multicolumn{7}{|c|}{ Pre-implantation } \\
\hline Groups & Adrenals & Liver & Pancreas & Lungs & Kidneys & Thymus \\
\hline Control & - & - & - & - & - & - \\
\hline $37.5 \mathrm{mg} / \mathrm{kg}$ & - & - & - & - & - & - \\
\hline $\begin{array}{l}187.5 \\
\mathrm{mg} / \mathrm{kg}\end{array}$ & Far from the kidney (1) & $\begin{array}{l}\text { Adhered to Stomach } \\
\text { (1) }\end{array}$ & $\begin{array}{l}\text { Nodules } \\
\text { (1) }\end{array}$ & $\begin{array}{l}\text { Nodule and/or edema } \\
\text { (2) }\end{array}$ & $\begin{array}{l}\text { Nodules } \\
\text { (1) }\end{array}$ & - \\
\hline $375 \mathrm{mg} / \mathrm{kg}$ & $\begin{array}{l}\text { Adhered to the kidney with nodules over and near the } \\
\qquad \text { organ (1) }\end{array}$ & - & - & $\begin{array}{c}\text { Nodule and/or edema } \\
\text { (3) }\end{array}$ & - & - \\
\hline \multicolumn{7}{|c|}{ Organogenesis } \\
\hline Groups & Adrenals & Liver & Pancreas & Lungs & Kidneys & Thymus \\
\hline Control & - & - & - & - & $\begin{array}{c}\text { Nodules } \\
\text { (2) }\end{array}$ & $\begin{array}{l}\text { Nodules } \\
\text { (1) }\end{array}$ \\
\hline $37.5 \mathrm{mg} / \mathrm{kg}$ & - & - & Nodules (2) & - & Nodules (2) & Nodules (3) \\
\hline $\begin{array}{c}187.5 \\
\mathrm{mg} / \mathrm{kg}\end{array}$ & - & - & $\begin{array}{c}\text { Nodules } \\
\text { (1) }\end{array}$ & - & $\begin{array}{c}\text { Nodules } \\
\text { (7) }\end{array}$ & - \\
\hline $375 \mathrm{mg} / \mathrm{kg}$ & - & - & $\begin{array}{c}\text { Nodules } \\
\text { (1) }\end{array}$ & - & - & $\begin{array}{c}\text { Nodules } \\
\text { (8) }\end{array}$ \\
\hline
\end{tabular}

Subtitle: The numbers in parentheses represent the number of animals carrying the changes, and the symbol (-) represents no organ changes.

Source: Silva JL, et al., 2019. 
The maternal organs evaluated in the organogenesis indicated a significant reduction of 21 and $24 \%$ of absolute pancreas masses in the E2 and E3 groups, respectively, when compared to the control group. Also, the relative pancreas masses showed a significant reduction of $25.8 \%$ in the E3 group and $16 \%$ in the E1 and E2 groups, when compared to the control (Table 2).

Table 2 - Effects of oral administration of eugenol on the absolute $(\mathrm{g})$ and relative (\%) masses of maternal organs during the organogenesis phase in Wistar rats.

\begin{tabular}{|c|c|c|c|c|c|c|c|c|}
\hline \multirow[b]{2}{*}{ Organs } & \multirow{2}{*}{$\begin{array}{l}\text { Control } \\
\text { Mass (g) }\end{array}$} & \multirow[b]{2}{*}{ Relative (\%) } & \multicolumn{2}{|c|}{$\begin{array}{c}\text { E1 } \\
(37.5 \mathrm{mg} / \mathrm{kg})\end{array}$} & \multicolumn{2}{|c|}{$\begin{array}{c}\text { E2 } \\
(187.5 \mathrm{mg} / \mathrm{kg})\end{array}$} & \multicolumn{2}{|c|}{$\begin{array}{c}\text { E3 } \\
(375 \mathrm{mg} / \mathrm{kg})\end{array}$} \\
\hline & & & Mass (g) & Relative (\%) & Mass (g) & Relative (\%) & Mass (g) & Relative (\%) \\
\hline Ovaries & $0.11 \pm 0.01$ & $0.04 \pm 0.00$ & $0.12 \pm 0.00$ & $0.04 \pm 0.00$ & $0.12 \pm 0.01$ & $0.04 \pm 0.00$ & $0.09 \pm 0.01$ & $0.03 \pm 0.00$ \\
\hline Placentas & $4.93 \pm 0.66$ & $1.53 \pm 0.17$ & $5.17 \pm 0.35$ & $1.64 \pm 0.07$ & $5.05 \pm 0.19$ & $1.66 \pm 0.07$ & $4.74 \pm 0.45$ & $1.46 \pm 0.10$ \\
\hline Pancreas & $0.99 \pm 0.07$ & $0.31 \pm 0.02$ & $0.89 \pm 0.02$ & $0.26 \pm 0.01^{*}$ & $0.78 \pm 0.04^{*}$ & $0.26 \pm 0.01^{*}$ & $0.75 \pm 0.05^{* \star}$ & $0.23 \pm 0.01^{* *}$ \\
\hline Thymus & $0.36 \pm 0.02$ & $0.11 \pm 0.01$ & $0.34 \pm 0.03$ & $0.01 \pm 0.00$ & $0.31 \pm 0.02$ & $0.10 \pm 0.01$ & $0.31 \pm 0.03$ & $0.10 \pm 0.01$ \\
\hline Heart & $0.86 \pm 0.03$ & $0.27 \pm 0.01$ & $0.84 \pm 0.03$ & $0.25 \pm 0.01$ & $0.78 \pm 0.03$ & $0.26 \pm 0.01$ & $0.80 \pm 0.01$ & $0.25 \pm 0.01$ \\
\hline Lungs & $1.39 \pm 0.09$ & $0.44 \pm 0.02$ & $1.46 \pm 0.08$ & $0.44 \pm 0.02$ & $1.33 \pm 0.05$ & $0.44 \pm 0.02$ & $1.28 \pm 0.05$ & $0.40 \pm 0.01$ \\
\hline Liver & $12.14 \pm 0.48$ & $3.83 \pm 0.09$ & $12.78 \pm 0.30$ & $3.82 \pm 0.08$ & $12.22 \pm 0.75$ & $3.97 \pm 0.14$ & $12.69 \pm 0.40$ & $3.97 \pm 0.06$ \\
\hline Kidneys & $1.92 \pm 0.09$ & $0.61 \pm 0.02$ & $1.9 \pm 0.08$ & $0.56 \pm 0.02$ & $1.85 \pm 0.08$ & $0.61 \pm 0.02$ & $1.83 \pm 0.05$ & $0.57 \pm 0.02$ \\
\hline Adrenals & $0.10 \pm 0.01$ & $0.03 \pm 0.00$ & $0.09 \pm 0.00$ & $0.03 \pm 0.00$ & $0.19 \pm 0.09$ & $0.07 \pm 0.03$ & $0.08 \pm 0.00$ & $0.03 \pm 0.00$ \\
\hline Spleen & $0.57 \pm 0.03$ & $0.18 \pm 0.01$ & $0.53 \pm 0.02$ & $0.16 \pm 0.01$ & $0.54 \pm 0.03$ & $0.18 \pm 0.01$ & $0.60 \pm 0.03$ & $0.19 \pm 0.01$ \\
\hline Stomach & $1.49 \pm 0.06$ & $0.47 \pm 0.01$ & $1.56 \pm 0.06$ & $0.47 \pm 0.01$ & $1.37 \pm 0.11$ & $0.45 \pm 0.03$ & $1.54 \pm 0.06$ & $0.49 \pm 0.03$ \\
\hline Pregnancy uterus & $59.37 \pm 7.25$ & $18.38 \pm 1.85$ & $68.32 \pm 3.93$ & $21.63 \pm 0.57$ & $59.2 \pm 7.59$ & $19.46 \pm 2.46$ & $68.25 \pm 6.94$ & $20.97 \pm 1.56$ \\
\hline
\end{tabular}

Subtitle: The values represent the mean \pm S.E.M. analyzed by one-way ANOVA, followed by Dunnett's test ( $\mathrm{n}=9 / \mathrm{group})$ and the statistical differences represent ${ }^{*} p<0.05,{ }^{* *} p<0.01,{ }^{* \star \star *} p<0.0001$, respectively. Relative organ masses were calculated by the ratio of organ weight and body weight on the last day of gestation $x 100$.

Source: Silva JL, et al., 2019.

REAS/EJCH | Vol.11(16) | e1864 | DOI: https://doi.org/10.25248/reas.e1864.2019 Página 8 de 15 
Regarding reproductive parameters during the pre-implantation phase, there was a significant reduction in implantations in the E1 (85.7\%) and E2 (86.8\%) groups compared to control (100\%). Also, were significantly increased the pre-implantation loss in the E1 (28.6\%) and E2 (25\%) groups, the reabsorption index (20.2\%) and post-implantation loss in the E3 group (20.2\%) when compared to their respective control groups (8.3\%) (Table 3).

Table 3 - Reproductive parameters of eugenol-treated Wistar rats in pre-implantation.

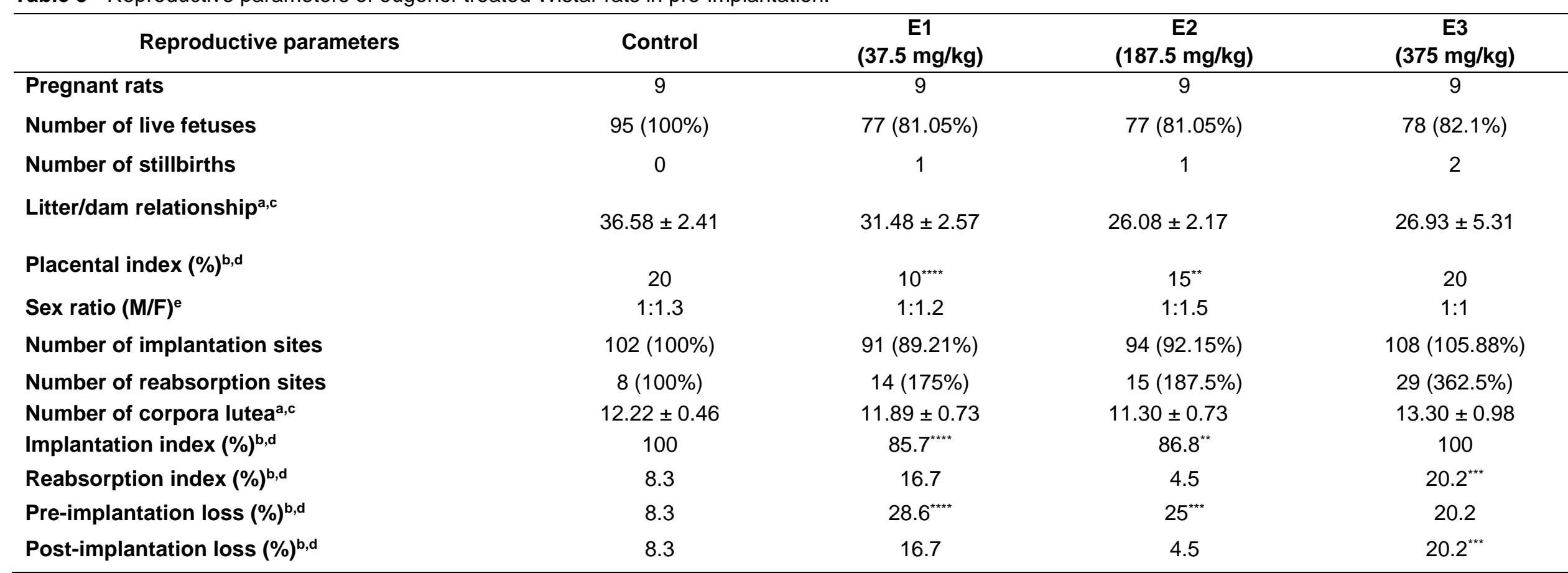

Subtitle: Placental indexes [viable placental mass $(\mathrm{g})$ / litter mass $(\mathrm{g}) \times 100$ ], implantation index [total number of implantation sites / total number of corpora lutea $\mathrm{x}$ 100], reabsorption index [total number of reabsorption / total number of implantation sites $x$ 100], pre-implantation loss [(number of corpora lutea minus number of viable implantation sites) / number of corpora lutea $x$ 100], post-implantation loss [(number of implantations minus number of live fetuses / number of implantations $x$ $100]$ and the sex ratio [total number of male fetuses / total number of female fetuses]. Values were expressed as mean \pm S. E.M. or median ${ }^{b}$. Statistical analyses were performed using one-way ANOVA, followed by Dunnett's ${ }^{c}$ post-test, Kruskal-Wallis test followed by Dunn's ${ }^{d}$ post-test and Pearson'se chi-square test. Statistically different values of the control group represent $\left.{ }^{*} p<0.05,{ }^{* *} p<0.01,{ }^{* * * *} p<0.0001\right)$.

Source: Silva JL, et al., 2019. 
External analysis of the maternal organs revealed the marked presence of stiffened nodules in the kidneys, thymus, and pancreas of the progenitors treated during organogenesis (Frame 1).

During organogenesis, the reproductive parameters showed an increase in the number of implantation sites in the E1 (114.9\%) compared to control (100\%). The pre-implantation loss was lower in the E1 (10\%), E2 (9.1\%) and E3 (10\%) groups when compared to control (27.3\%). There was no post-implantation loss in the E2 and E3 groups, and the treated E1 group (5\%) did not differ significantly from the control (16.7\%) (Table 4).

Table 4 - Reproductive parameters of eugenol-treated Wistar rats in organogenesis.

\begin{tabular}{|c|c|c|c|c|}
\hline Reproductive parameters & Control & $\begin{array}{c}\mathrm{E1} \\
(37.5 \\
\mathrm{mg} / \mathrm{kg})\end{array}$ & $\begin{array}{c}\text { E2 } \\
(187.5 \\
\mathrm{mg} / \mathrm{kg})\end{array}$ & $\begin{array}{c}\text { E3 } \\
(375 \\
\mathrm{mg} / \mathrm{kg})\end{array}$ \\
\hline $\begin{array}{l}\text { Pregnant rats } \\
\text { Number of live fetuses } \\
\text { Number of stillbirths }\end{array}$ & $\begin{array}{c}9 \\
75(100 \%) \\
0\end{array}$ & $\begin{array}{c}9 \\
96(128 \%) \\
0\end{array}$ & $\begin{array}{c}9 \\
90(120 \%) \\
0\end{array}$ & $\begin{array}{c}9 \\
85(113.3 \%) \\
0\end{array}$ \\
\hline Litter/dam relationship ${ }^{a, c}$ & $0.18 \pm 0.02$ & $0.21 \pm 0.01$ & $0.23 \pm 0.02$ & $0.19 \pm 0.01$ \\
\hline $\begin{array}{l}\text { Placental index }(\%)^{b, d} \\
\text { Sex ratio }(M / F)^{e}\end{array}$ & $\begin{array}{c}12 \\
1: 0.6\end{array}$ & $\begin{array}{c}11^{*} \\
1: 1.2\end{array}$ & $\begin{array}{l}11^{*} \\
1: 1\end{array}$ & $\begin{array}{c}11^{*} \\
1: 1.5\end{array}$ \\
\hline Number of implantation sites & $94(100 \%)$ & $\begin{array}{c}108 \\
(114.89 \%)\end{array}$ & $92(97.87 \%)$ & $91(96.8 \%)$ \\
\hline Number of reabsorption sites & $19(100 \%)$ & $11(57.89 \%)$ & $2(10.52 \%)$ & $6(31.57 \%)$ \\
\hline Number of corpora lutea & $11,78 \pm 0,36$ & $11,60 \pm 0,52$ & $11,33 \pm 0,69$ & $11,22 \pm 0,57$ \\
\hline Implantation index $(\%)^{\mathrm{b}, \mathrm{d}}$ & 90,91 & $96,43^{*}$ & $100^{* * * *}$ & 90,91 \\
\hline Reabsorption index $(\%)^{b, d}$ & 16,67 & $0^{* \star * \star}$ & $0^{* * * *}$ & $0^{\star \star * \star *}$ \\
\hline $\begin{array}{l}\text { Pre-implantation loss }(\%)^{b, d} \\
\text { Post-implantation loss }(\%)^{b, d}\end{array}$ & $\begin{array}{l}27.27 \\
16.67 \\
\end{array}$ & $\begin{array}{c}10^{* *} \\
5\end{array}$ & $\begin{array}{l}9.09+\cdots * \\
0^{*+*+*}\end{array}$ & $\begin{array}{l}10^{* *} \\
0^{* * * *}\end{array}$ \\
\hline
\end{tabular}

Subtitle: Placental index[viable placental mass $(\mathrm{g}) /$ litter mass $(\mathrm{g}) \times 100]$, implantation index[total number of implantation sites/total number of corpora lutea $x$ 100], reabsorption index [total number of reabsorption/total number of implantation sites $\times 100$ ], pre-implantation loss [(number of corpora lutea minus number of viable implantation sites) / number of corpora lutea $\times 100]$, post-implantation loss [(number of implantations minus number of live fetuses) /number of implantations $x 100$ ) and the sex ratio [total number of male fetuses / total number of female fetuses]. Values were expressed as meana \pm S.E.M. or medianb. Statistical analyses were performed using one-way ANOVA, followed by Dunnett'sc post-test, Kruskal-Wallis test followed by Dunn'sd post-test and Pearson'se chi-square test. Statistically different values of the control group represent ${ }^{*} p<0.05$, $\left.{ }^{\star *} \mathrm{p}<0.01,{ }^{* \star * *} \mathrm{p}<0.0001\right)$.

Source: Silva JL, et al., 2019.

During pre-implantation, there was a statistically significant reduction in placental index in the E1 (10\%) and E2 (15\%) groups when compared to the control group (20\%) (Table 3). While in organogenesis, these indexes showed a statistically significant reduction in all treated groups $(11 \%)$ compared to their respective controls (12\%) (Table 4). Regarding embryo-fetal toxicity, no significant differences were observed in fetal masses, sex ratio, or maternal-fetal relationship in both gestational phases (pre-implantation and organogenesis). However, there was a record of stillbirth (1/77) in the E1 and E2 groups and two stillbirths (2/78) in the E3 group in the pre-implantation (Table 3).

Visceral analyses showed pulmonary artery dilatation, bladder dilation, and palate grooves of the fetuses analyzed (data not shown). Skeletal analyses identified statistically significant bone malformations such as proximal phalanx agenesis of anterior and posterior paws, reduction of the number of cervical vertebrae, shortening of the ribs, incomplete ossification of the squamous bone of the head. Bone malformations related to incomplete ossification and morphological alteration of the sternum (butterfly shape) were also significant (Table 5). 
Table 5 - Relationship of skeletal malformations of fetuses of eugenol-treated females during organogenesis.

\begin{tabular}{|c|c|c|c|c|}
\hline Skeletal malformations & Control & $\begin{array}{c}\mathrm{E} 1 \\
(37.5 \\
\mathrm{mg} / \mathrm{kg}) \\
\end{array}$ & $\begin{array}{l}\text { E2 } \\
(187.5 \\
\mathrm{mg} / \mathrm{kg})\end{array}$ & $\begin{array}{c}\text { E3 } \\
(375 \\
\mathrm{mg} / \mathrm{kg}) \\
\end{array}$ \\
\hline $\begin{array}{l}\text { Agenesis of proximal phalanges } \\
\text { of anterior paws }\end{array}$ & $\begin{array}{c}8 / 34 \\
(23.5 \%)\end{array}$ & $\begin{array}{c}19 / 45 \\
(42.2 \%)^{*}\end{array}$ & $\begin{array}{c}10 / 44 \\
(18.5 \%)\end{array}$ & $6 / 38(15.8 \%)$ \\
\hline $\begin{array}{l}\text { Agenesis of proximal phalanges } \\
\text { of posterior paws }\end{array}$ & $\begin{array}{c}10 / 34 \\
(29.4 \%)\end{array}$ & $\begin{array}{c}26 / 45 \\
(57.8 \%)\end{array}$ & $\begin{array}{c}17 / 44 \\
(38.6 \%)\end{array}$ & 18/38 (47.3\%) \\
\hline Absence of cervical vertebrae & $\begin{array}{c}1 / 34 \\
(2.9 \%)\end{array}$ & $\begin{array}{c}45 / 45 \\
(100 \%)^{* * * *}\end{array}$ & $\begin{array}{c}37 / 44 \\
(84.1 \%)\end{array}$ & $38 / 38(100 \%)^{* * * *}$ \\
\hline Shortened ribs & $0 / 34(0 \%)$ & $0 / 45(0 \%)$ & $3 / 44(6.8 \%)$ & $0 / 38(0 \%)$ \\
\hline $\begin{array}{l}\text { Incomplete ossification of the } \\
\text { squamous }\end{array}$ & $0 / 34(0 \%)$ & $\begin{array}{c}16 / 45 \\
(35.6 \%)^{* *}\end{array}$ & $\begin{array}{c}10 / 44 \\
(22.7 \%)\end{array}$ & $8 / 38(21.0 \%)$ \\
\hline $\begin{array}{l}\text { Incomplete ossification of the } \\
\text { sternebrae }\end{array}$ & $\begin{array}{c}19 / 34 \\
(55.8 \%)\end{array}$ & $\begin{array}{c}16 / 45 \\
(35.6 \%)\end{array}$ & $\begin{array}{c}25 / 44 \\
(56.8 \%)\end{array}$ & $29 / 38(76.3 \%)^{* *}$ \\
\hline Butterfly shape sternum & $\begin{array}{c}1 / 34 \\
(2.9 \%)\end{array}$ & $0 / 45(0 \%)$ & $4 / 44(9.1 \%)$ & $16 / 38(29.6 \%)^{* * * *}$ \\
\hline $\begin{array}{l}\text { Incomplete ossification of } \\
\text { manubrium }\end{array}$ & $\begin{array}{c}1 / 34 \\
(2.9 \%)\end{array}$ & $0 / 45(0 \%)$ & $0 / 44(0 \%)$ & $0 / 38(0 \%)$ \\
\hline Absence of xiphoid process & $0 / 34(0 \%)$ & $0 / 45(0 \%)$ & $0 / 44(0 \%)$ & $2 / 38(5.3 \%)$ \\
\hline $\begin{array}{l}\text { Agenesis of the last sternal } \\
\text { center }\end{array}$ & $0 / 34(0 \%)$ & $1 / 45(2.2 \%)$ & $0 / 44(0 \%)$ & $0 / 38(0 \%)$ \\
\hline
\end{tabular}

Subtitle: The results of fetal skeletal malformations were organized from the relationship between the number of affected fetuses/ total number of fetuses analyzed. Values in parentheses represent the percentage of skeletal malformations observed. Statistical differences between treated and control groups were calculated by Pearson's chi-square test, ${ }^{*} p<0.05,{ }^{* *} p<0.01,{ }^{* * *} p<0.0001$ ).

Source: Silva JL, et al., 2019.

\section{DISCUSSION}

The results obtained after treatment with eugenol showed that female rats had a significant reduction in food intake in both gestational phases, but there was no change in body weight. Wang M, et al. (2019) compared the effect of 13 pesticides on female rats body weight during 14,21, 28, 42 and 70 days and concluded that there is a time-dependent toxicity relationship, where shorter exposures (14 days) had less pronounced effects. Treatment with eugenol lasted six days on pre-implantation and 10 days on organogenesis, both less than 14 days, indicating that the exposure time may not have been sufficient to affect female body weight gain, but the reduction in the ingestion of food and water can be the beginning of systemic toxicity.

The reduction in ovarian mass during pre-implantation observed after oral administration of eugenol at the highest dose may indicate a reduction in ovarian activity. Similar results were observed from the intramuscular administration of eugenol ( $0.2 \mathrm{ml} /$ day/animal) in female rats, where the significant presence of atretic ovarian follicles concerning healthy follicles, associated with ovarian mass reduction, indicated antiestrogenic activity of this substance (KULKARNI DS, 2011). 
There was also a reduction in absolute and relative placental masses after eugenol administration at all evaluated doses. The placenta is an organ capable of interacting with xenobiotics from specific enzymemediated oxidation, reduction, or conjugation reactions. This organ is also capable of metabolic reactions involving CYP450 complex enzymes (AL-ENAZY S, et al., 2017). In the presence of these enzymes, eugenol starts to perform a pro-oxidant activity, resulting in a metabolic intermediate with cytotoxic capacity called quinone-methide (THOMPSON DC, et al., 1991).

Eugenol in the presence of hydrogen peroxide can be metabolized in vitro by placental peroxidases, causing placental dysfunction (ZHANG R, et al., 2000). Given this, we can correlate oxidative stress to constriction of blood vessels, with a consequent reduction of placental mass and activity.

In order to evaluate the involvement of eugenol on placental function, we calculated the placental index, a parameter that indicates the relationship of nutrient exchange between mother and fetus, mediated by the placenta (KINGDOM JCP and KAUFMANN P, 1999). Therefore, the reduction in placental indexes, associated with the reduction in placental mass and constriction of blood vessels, suggest that eugenol can cross the transplacental barrier and interfere with maternal metabolism, exerting a toxic action on the fetus.

The observation of stillbirths, reduction on implantation indexes, increase in pre-and post-implantation loss and reabsorption, demonstrated in this study, are indicators of maternal, embryonic, and fetal toxicity resulting from the administration of eugenol. These findings may be correlated with inhibition of estrogen secretion during the pre-implantation, which interferes with the process of uterine epithelial proliferation and disturbs the blastocyst implantation in the uterus (SINGH MM, et al., 1996), increasing embryonic death (DOMARACKÝ $\mathrm{M}$, et al., 2007). These changes reinforce the contraindication for eugenol use during the initial gestational period. The demonstration of pulmonary edema, hepatic, renal, and adrenal alterations observed after the treatment of pregnant rats with eugenol during the pre-implantation is another toxicity indicator of this compound. Similar findings have been reported after prolonged administration of this substance in rats (SOBER HA, et al., 1950), hamsters (LAVOIE EJ, et al., 1986), rabbits (MCDONALD JW and HEFFNER JE, 1991), and frogs (GOULET F, et al., 2011).

The presence of stiffened nodules in the pancreas of eugenol-treated females in the pre-implantation and organogenesis phases may have obstructed pancreatic ducts, impairing secretory activity, deregulating the available calcium concentration and recruiting intrapancreatic enzymes to trigger an inflammatory process in the affected organ. Such inflammation triggers a systemic response, depressing the immune system, affecting various organs such as the liver, lungs, and kidneys (PÉREZ S, et al., 2015). This metabolic imbalance may cause a reduction in the pancreas mass and facilitate the formation of the observed nodules.

Goulet F, et al. (2011) observed dose-dependent lesions on kidneys, liver, and lungs of African frogs (Xenopus laevis) immersed in eugenol aqueous solution $(375 \mu \mathrm{l} / \mathrm{L})$ for 24 and $72 \mathrm{~h}$. These lesions were reversible after 15 days from exposure interruption. This work suggests that stopping eugenol treatment allowed the reversal of the observed toxic effects.

The reversibility of the toxic action after interruption of exposure to the agent could explain the low presence of nodules in the maternal organs during pre-implantation, whose treatment lasted six days, with a more extended recovery period ( 15 days) when compared with the groups treated in the organogenesis, where the treatment was longer (10 days) and the recovery time shorter (6 days). Visceral and skeletal analyzes of fetuses were performed only in organogenesis phase to investigate the teratogenic potential of eugenol.

The visceral changes were not statistically significant. On the other hand, skeletal changes were significant when compared to control. Bone tissue homeostasis is known to be related to maintenance of estrogen levels, so the decrease of this hormone can cause bone mass loss (FALONI APS and CERRI PS, 2007).

In this way, the antiestrogenic action of eugenol may have reduced estrogen levels in the body of treated females, resulting in delayed fetal bone development during organogenesis. A previous study indicates that some monoterpenes can inhibit bone reabsorption by an unclear mechanism of action (MÜHLBAUER RC, et al., 2003). This ability may also be present in eugenol and have partially caused the observed skeletal changes. 


\section{CONCLUSION}

The reproductive toxicological study showed eugenol interferes with maternal reproductive capacity and causes embryo-fetal toxicity, mainly in pre-implantation, and contributes to fetal malformations in the organogenesis phase. However, further studies are needed to establish a safe dose of use of this compound and to elucidate the mechanisms of action associated with the effects of continuous use.

\section{ACKNOWLEDGMENT}

We would like to thank the National Council for Scientific and Technological Development (CNPq) for their assistance in the postgraduate scholarship (Ph.D.), case number 140554/2015-7, to author Jamilka Leopoldina da Silva during the development of this work.

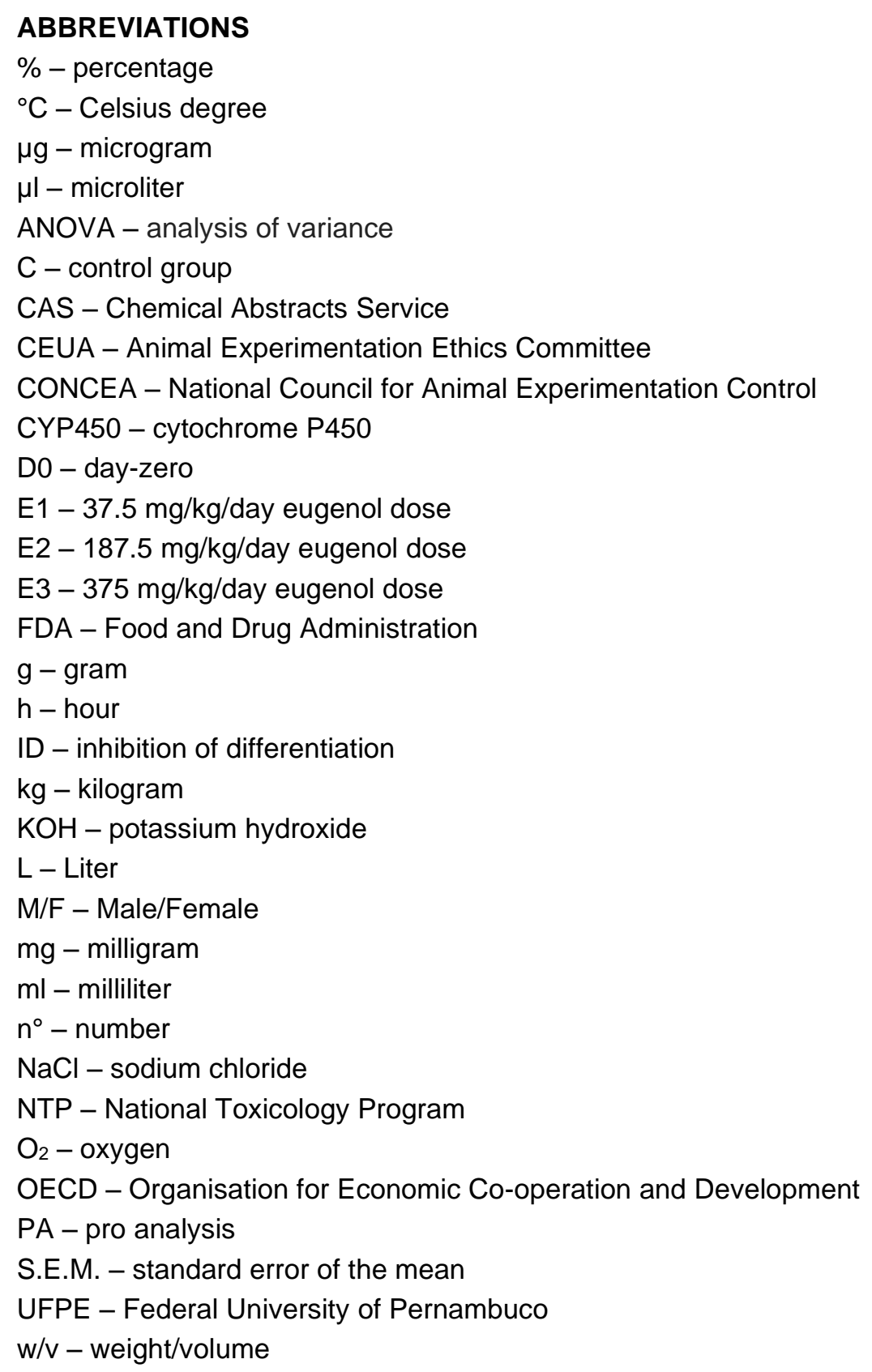




\section{REFERENCES}

1. AL-ENAZY S, et al. Placental control of drug delivery. Advanced Drug Delivery Reviews, 2017; 116: 63-72.

2. ALIVERTI V, et al. The extent of fetal ossification as an index of delayed development in teratogenic studies on the rat. Teratology, 1979; 20 (2): 237-242.

3. BÓ WD, et al. Eugenol reduces acute pain in mice by modulating the glutamatergic and tumor necrosis factor alpha (TNFa) pathways. Fundamental \& Clinical Pharmacology, 2013; 27 (5): 517-525.

4. BRASIL. Ministério da Ciência, Tecnologia e Inovação, Conselho Nacional de Controle de Experimentação Animal (CONCEA). Diretrizes da prática de eutanásia do CONCEA. Brasília, DF, 2015.

5. CHARANTIMATH S, OSWAL R. Herbal Therapy in Dentistry: A Review. Innovative Journal of Medical and Health Science, 2011; 1 (1): 1-4.

6. CHATTERJEE D, BHATTACHARJEE P. Use of eugenol-lean clove extract as a flavoring agent and natural antioxidant in mayonnaise: product characterization and storage study. Journal of Food Science and Technology, $2015 ; 52$ (8): 4945-4954.

7. COOPER RL, et al. Methods in Toxicology. Monitoring of estrous cycle in the laboratory rodent by vaginal lavage. $3^{\text {th }}$ ed. New York: Academic press, 1993; 45-56.

8. COSTA-SILVA JH, et al. Toxicological reproductive study of Carapa guianensis Aublet (andiroba) in female Wistar rats. Acta Farmaceutica Bonaerense, 2006; 25: 425-428.

9. DOMARACKÝ $\mathrm{M}$, et al. Effects of selected plant essential oils on the growth and development of mouse preimplantation embryos in vivo. Physiological Research, 2007; 56 (1): 97-104.

10. FALONI APS, CERRI PS. Mecanismos celulares e moleculares do estrógeno na reabsorção óssea. Revista de Odontologia da UNESP, 2007; 36 (2): 181-188.

11. FDA. 2018. Food additive status list. Silver Spring, MD. Available in: https://www.fda.gov/food/food-additivespetitions/food-additive-status-list. Acess in: 20 ago. 2019.

12. GOULET F, et al. Evaluation of the toxicity of eugenol at anesthetic doses in African clawed frogs (Xenopus laevis). Toxicologic Pathology, 2011; 39 (3): 471-477.

13. GÜLÇIN I. Antioxidant activity of eugenol: A structure-activity relationship study. Journal of Medicinal Food, $2011 ; 14$ (9): 975-985.

14. KINGDOM JCP, KAUFMANN P. Oxygen and Placental Vascular Development. Advances in Experimental Medicine and Biology, 1999; 474: 259-275.

15. KULKARNI DS. Eugenol induced changes in reproductive cycle of female albino rats. Bioscience Biotechnology Research Communications, 2011; 4 (1): 98-101.

16. LAVOIE EJ, et al. Toxicity studies on clove cigarette smoke and constituents of clove: determination of the LD50 of eugenol by intratracheal instillation in rats and hamsters. Archives of Toxicology, 1986; 59 (2): 78-81.

17. LIU, H. et al. Embryotoxicity estimation of commonly used compounds with embryonic stem cell test. Molecular medicine reports, $2017 ; 16(1): 263-271$.

18. MCDONALD JW, HEFFNER JE. Eugenol Causes Oxidant-mediated Edema in Isolated Perfused Rabbit Lungs 14. The American Review of Respiratory Disease, 1991; 143: 806-809.

19. MÜHLBAUER RC, et al. Common herbs, essential oils, and monoterpenes potently modulate bone metabolism. Bone, 2003; 32 (4): 372-380.

20. NAEEM A, et al. Essential oils: Brief background and uses. Annals of Short Reports, 2018; 1 (1): 1006.

21. NTP. 1999. Final Report on the Developmental Toxicity of Isoeugenol (CAS No. 97-54-1) in Sprague-Dawley CD (Trade Name) Rats Exposed on Gestation Days 6-19: National Technical Reports Library Publising. Available in: https://ntrl.ntis.gov/NTRL/dashboard/searchResults/titleDetail/PB2000105138.xhtml. Acess in: 04 oct. 2019.

22. OECD. 2016. Test No. 421: Reproduction/Developmental Toxicity Screening Test, OECD Guidelines for the Testing of Chemicals, Section 4. Paris: OECD Publishing. Available in: https://read.oecd-ilibrary.org/environment/test-no-421reproduction-developmental-toxicity-screening-test_9789264264380-en\#page1. Acess in: 19 ago. 2019.

23. PÉREZ S, et al. Redox signaling in acute pancreatitis. Redox Biology, 2015; 5: 1-14.

24. SAID MM, RABO MM. Neuroprotective effects of eugenol against aluminium induced toxicity in the rat brain. Archives of Industrial Hygiene and Toxicology, 2017; 68 (1): 27-36.

25. SANTIN JR, et al. Gastroprotective activity of essential oil of the Syzygium aromaticum and its major component eugenol in different animal models. Naunyn-Schmiedeberg's Archives of Pharmacology, 2011; 383 (2): 149-158.

26. SHARMA UK, et al. Medicinal attributes of major phenylpropanoids present in cinnamon. BMC Complementary and Alternative Medicine, 2016; 16 (1): e156.

27. SILVA FFM, et al. Eugenol derivatives: synthesis, characterization, and evaluation of antibacterial and antioxidant activities. Chemistry Central Journal, 2018; 12 (1): e34.

28. SINGH MM, et al. Uterine estradiol and progesterone receptor concentration, activities of certain antioxidant enzymes and dehydrogenases and histoarchitecture in relation to time of secretion of nidatory estrogen and high endometrial sensitivity in rat. The Journal of Steroid Biochemistry and Molecular Biology, 1996; 59 (2): 215-224.

29. SOBER HA, et al. Toxicity of Eugenol: Determination of LD50 on Rats. Proceedings of the Society for Experimental Biology and Medicine, 1950; 73 (1): 148-151.

30. SOLECKI R. et al. Harmonisation of rat fetal skeletal terminology and classification. Report of the third workshop on the terminology in developmental toxicology: Berlin, 14-16 September 2000. Reproductive Toxicology, $2001 ; 15$ (6): 713-721. 
31. STAPLES RE, SCHNELL VL. Refinements in rapid clearing technic in the koh-alizarin red $S$ method for fetal bone. Stain Technology, 1964; 39: 61-63.

32. THOMPSON DC, et al. Metabolism and cytotoxicity of eugenol in isolated rat hepatocytes. Chemico-biological Interactions, 1991; 77 (2): 137-147.

33. WANG M, et al. Relationship between magnitude of body weight effects and exposure duration in mammalian toxicology studies and implications for ecotoxicological risk assessment. Environmental Sciences Europe, $2019 ; 31$ (1): e38.

34. WANG X, et al. Support for Natural Small-Molecule Phenols as Anxiolytics. Molecules, 2017; 22(12): e2138.

35. WILSON J. Teratology: principles and techniques. Methods for administering agents and detecting malformations in experimental animals. Chicago: University of Chicago Press, 1965; 262-277.

36. ZHANG R, et al. Oxidation of eugenol by purified human term placental peroxidase. Placenta, $2000 ; 21$ (2): $234-240$. 